\title{
The Effects of Zinc on the Morphology of Sickle Red Blood Cell Ghosts as Observed by Scanning Electron Microscopy
}

\author{
W.C. KRUCKEBERG, F.J. OELSHLEGEL, Jr. ${ }^{1}$, S.H. SHORE, P.E. SMOUSE, \\ and G.J. BREWER \\ Department of Human Genetics, University of Michigan Medical School, \\ Ann Arbor, 1137 E. Catherine Street, Michigan 48109, U.S.A. \\ 1 Department of Preventive Medicine, University of Mississippi \\ Medica1 Center Jackson, Mississippi 39216, U.S.A.
}

Summary: The objective of these studies is to define the role of zinc in RBC ghost morphology specifically in comparison to the echinocytogenic effects of calcium. Erythrocyte ghosts were prepared from patients with sickle cell anemia, treated with zinc and/or calcium and the resulting cell morphology studied by scanning electron microscopy. Our results showed that zinc consistent1y and significantly antagonized the echinocytogenic effect of calcium. A simple log linear statistical model was used to evaluate the data and supported this conclusion. We discuss the potential significance of these findings to the effect of zinc treatment on patients with sickle cell anemia.

Key words: Sickle cell anemia - calcium - zinc - erythrocyte - echinocyte electron microscopy

In the normal red blood cell (RBC) calcium levels are closely controlled. Not only is the cell membrane relatively impermeable to calcium but the membrane also contains a Ca++-ATPase enzyme which moves calcium out of the cell against a hundred-fold concentration gradient (19). It has been well documented that abnormal calcium accumulation in RBC's and ghosts leads to aberrant morphology and cell function (see Discussion). For example, WEED and CHAILLEY (23) and others have noted that RBC calcium accumulation will produce what BESSIS (1) has termed a discocyte-echinocyte transformation, i.e., the formation of projections on the membrane surface. This calcium-induced echinogenesis can be prevented by preincubating the cell ghosts with sulfhydryl reagents or the repeated washing of ghost cell membranes prior to calcium treatment (17). These results implicate the membrane structural proteins as at least one element in calcium-induced echinogenesis. 
The main objective of this paper is to present data which we interpret as showing that zinc effectively antagonizes the calcium-induced discocyteechinocyte transformation in ghosts prepared from the red cells of patients with sickle cell anemia (SCA). Additionally, the presence of zinc in the ghost preparation is correlated with what appears to be a heretofore undescribed form of ghost. Finally, we have found that the compound trinitrocresol (TNC; 2, 4, 6-trinitro-3-methy1-phenol) previously used to stimulate calcium uptake by whole red cells (8), is an effective agent for inhibiting zinc uptake by such cells.

Our attention has been previously drawn to a calcium-zinc antagonism in the red cell membrane by studies which showed that zinc partially blocks the calcium-induced hemoglobin ( $\mathrm{Hb}$ ) retention in $\mathrm{RBC}$ ghosts (7), and further that zinc will displace the calcium which binds to RBC ghost membranes (4). Recent studies have suggested an important role for calcium in producing membrane damage in sickle red cells (9). Thus, the calcium-antagonizing effect of zinc may be useful in preventing membrane damage in sickle cells. In preliminary studies oral zinc therapy has produced hematologic and symptomatic improvement in uncontrolled trials $(3,5)$. Such zinc therapy significantly reduces the count of irreversibly sickled cells, giving objective evidence of an in vivo effect (3). We speculate that there may exist a relationship between these observations in that oral administration of zinc to SCA patients may result in zinc antagonism of the deleterious calcium at the level of the SCA RBC membrane.

\section{MATERIAL AND METHODS}

Fresh sickle red blood cells were washed three times by centrifugation with saline (buffy coat removed) and subjected to one of four treatments. One vol of packed whole cells was suspended in nine vol of either $3 \mathrm{mM} \mathrm{NaCl}$ (control), $1.5 \mathrm{mM} \mathrm{ZnSO}_{4}, 1 \mathrm{mM} \mathrm{CaCl}_{2}$ or both $\mathrm{ZnSO}_{4}$ and $\mathrm{CaCl}_{2}$. The $\mathrm{pH}$ of the hemolysates ranged from 6.51 to 6.87 . After 20 minutes stirring at room temperature the ghosts were centrifuged at $28,000 \mathrm{~g}$ for 10 minutes at $4^{\circ} \mathrm{C}$.

The supernatant was removed and the ghost cell pellet was resuspended for 20 minutes in five vol of $10 \mathrm{mM}$ Tris-HC1 ( $\mathrm{pH} \mathrm{7.4)}$ in saline (reconstituting buffer). The ghosts were than washed twice by centrifugation (International clinical centrifuge, Model CL, at top speed) with reconstituting buffer. These reconstituted single stage ghosts were fixed for scanning electron microscopy (SEM) by a two hour room temperature incubation in $2 \%$ glutaraldehyde in $0.2 \mathrm{M}$ sodium cacodylate ( $\mathrm{pH} 7.4$ ). The ghost cells were then subjected to progressive 15 minutes washings with ethanol $(20,40,60,80$ and $100 \%$ ethanol in water) and then ethanol/n-amyl acetate solutions (respectively by volume, $80 / 20,60 / 40.40 / 60,20 / 80$ and finally $100 \%$ amyl acetate). The ghost suspen- 
sions were critical point dried on a glass slide and gold coated to a thickness of $200 \mathrm{~A}$. The types of ghosts in the electron micrographs (1500 magnification, $30^{\circ}$ tilt, $15 \mathrm{kV}$ ) were counted by a technician blinded with respect to slide identification.

Ghost cell morphology was classified as one of three types (Fig. 1, A-C); (1) echinocytes, including types II, III and IV (1) (Fig. 1-A), (2) smooth (folded) cells (Fig. 1-B), or (3) flat cells (Fig. 1-C). The smooth (or folded) ghost cell shape was apparent in contrast to the echinocytic cells which showed the characteristic spicules projecting from the membrane. The flat ghost cell form was distinguished from the smooth and echinocytic forms, not only by the absence of spicules, but also by its primarily two-dimensional appearance on the slide. The two non-echinocytic membrane types described here are not discussed or classified by BESSIS (1) and until more experience is obtained with the effect of zinc on ghost cell morphology, the descriptive terms smooth (folded) or flat, two dimensional will be used to describe the membrane forms seen in Fig. 1 .

Electron microscope grid sections were randomly chosen for photographing, although those photographs were rejected which showed piles of aggregates of cells which made it difficult to distinguish discrete cell membranes. Having no means to quantitate the surface areas of membranes of the different cell types which were seen in the micrographs, we can only report that of the more than 150 photographs examined, the smooth or flat cell membranes appeared to be membranes of essentially whole cells, not cell fragments. Cell fragments and pieces, when occasionally seen, were not included in the cell counts.

Cells treated with TNC were prepared by incubating saline washed erythrocytes (hematocrit of 10 ) in $10 \mathrm{mM} \mathrm{NaCl}, 14 \mathrm{mM} \mathrm{KCl}, 2 \mathrm{mM} \mathrm{MgCl}_{2}, 1 \mathrm{mM}$ TNC, 10 $\mathrm{mM}$ Tris-HCl ( $\mathrm{pH}$ 7.4), and $\mathrm{ZnCl}_{2}$ and/or $\mathrm{CaCl}_{2}$ at concentrations given in the results. Non-TNC control cells were also used. Where designated, $3.5 \mu \mathrm{Ci} / \mathrm{ml}$ of $65 \mathrm{Zn++}$ or $3.2 \mu \mathrm{Ci} / \mathrm{ml}$ of ${ }^{45} \mathrm{Ca}++$ were added to these test solutions prior to incubation. The red cells were incubated for 16 hours at $4^{\circ} \mathrm{C}$ and then washed three times by centrifugation at $4^{\circ} \mathrm{C}$ (International clinical centrifuge, model PR-2) with a solution identical to the incubation buffer, except that the TNC and radionuclides were omitted. The cells were then counted for radioactivity or prepared for SEM as described by MATHESON and HOWLAND (12) with the exception that $2 \%$ glutaraldehyde and $0.2 \mathrm{M}$ sodium cacodylate buffers were used.

Reagent grade chemicals were used throughout these experiments. TNC was purchased from Du-Good Chemical Laboratory, St. Louis, Mo. The radioactive nuclides were obtained from New England Nuclear, Boston, Mass.

Sickle cell blood was obtained by venipuncture from three adult male patients housed in the Clinical Research Unit of the University of Michigan Hospital. Normal blood was obtained from healthy laboratory personnel. All blood was collected into zinc-free heparin and used within two hours.

Statistical treatment involved fitting the observed data to loglinear models (6). The results were evaluated by employing likelihood ratio test criteria, which lead asymptotically to standard chi-square distributions (22).

\section{RESULTS}

The morphological effects of zinc and/or calcium on sickle red blood cell ghosts were evaluated from electron micrographs of treated cells (Fig. 1,A-C). The combined results of the experiments with three separate patients' blood 


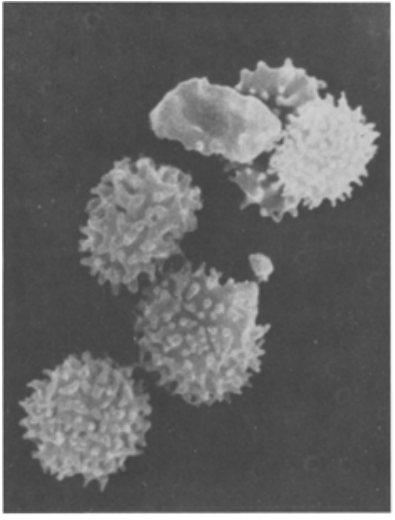

A

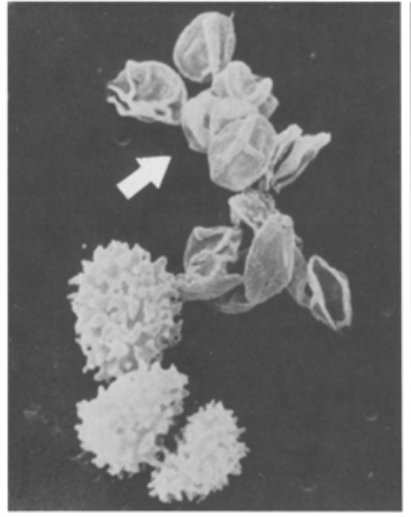

B

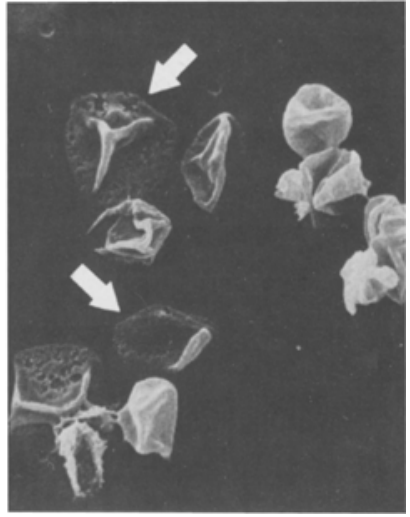

C

Fig. 1. The shape variations of sickle red blood cell ghosts as monitored by SEM. Sickle ghosts were treated with: $1 \mathrm{mM} \mathrm{CaCl}_{2}$, echinocytic cel1s (A); $1.5 \mathrm{mM} \mathrm{ZnSO}_{4}-1 \mathrm{mM} \mathrm{CaCl}_{2}$, smooth or folded cells (B, note arrow) or; $1.5 \mathrm{mM} \mathrm{ZnSO}{ }_{4}$, flat cells (C, note arrows)

cells are shown in Tab. 1. The expected values were derived from the raw data, using a statistical model which assumed that the logarithm percentage of echinocytes, smooth, or flat cells is a linear function of the amount of calcium or zinc added to the blood. As can be seen the observed values (weighted averages) and expected values agree quite closely. The coefficients have a positive sign for calcium effects and a negative sign for zinc effects on red cell ghost shape. As can be seen from Tab. 1, these effects are almost exactly equal in size.

A chi-square analysis of all the data is presented in Tab. 2 and yields three important pieces of information. First, experimental treatments account for a great deal of the variation, and are highly significant $(p<.001)$. Second, the effects of zinc and calcium are largely additive (although of opposite sign), and no interaction between them is necessary to account for the results. Third, the residual variation is considerable. This residual represents varied responses of different subjects to the different treatments. It is not possible to determine from the results whether these differences represent experimental noise or true genotypic differences and this question must remain open pending further experiments. We can measure treatment differences relative to this residual, however, to obtain conservative tests. If each chi square is divided by its degrees of freedom, and if the resulting "mean squares" are divided by the "mean square" for the residual, we obtain 


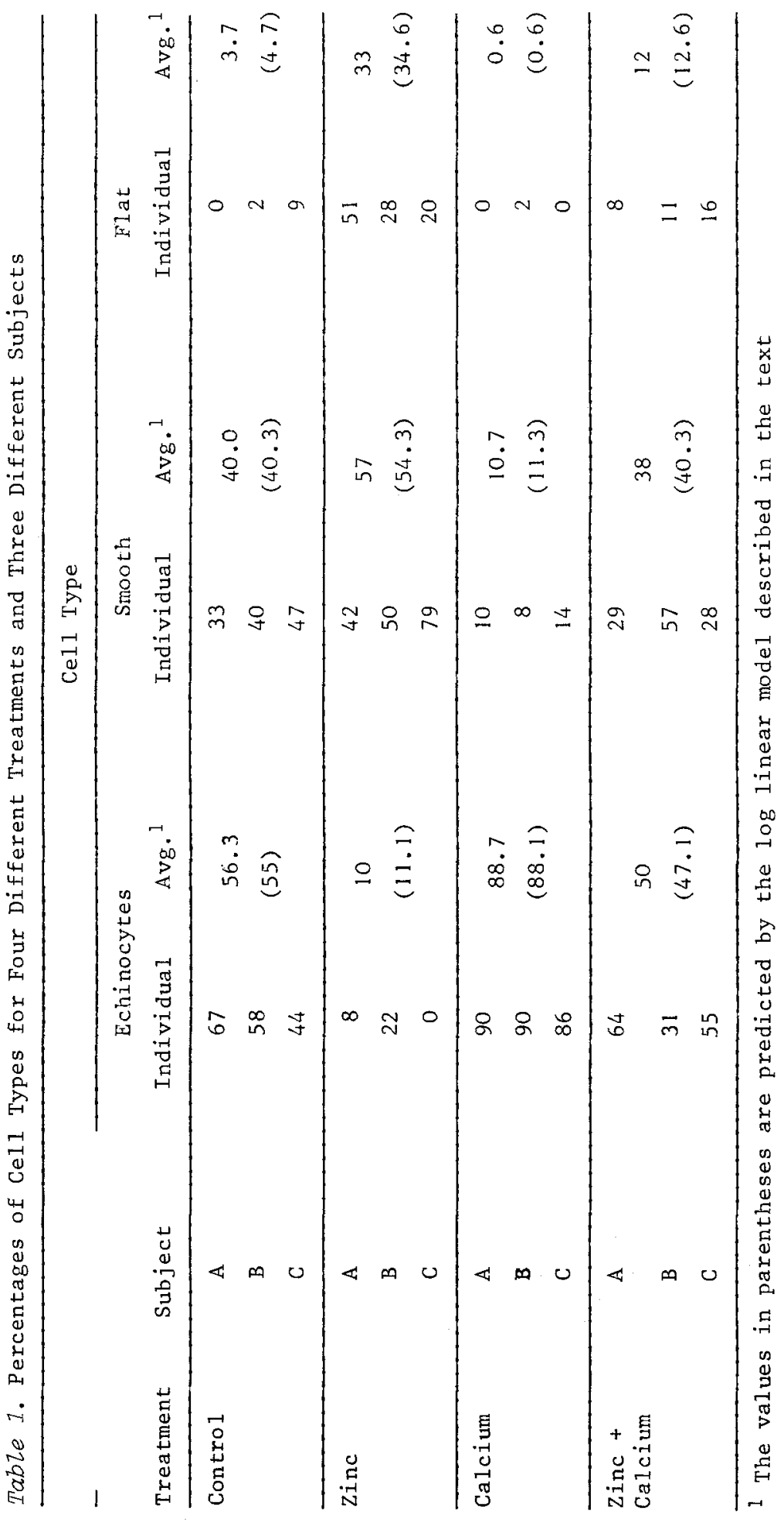


Table 2. Chi-Square Analysis (and Approximate F-Tests) of Treatment Effects on Red Cell Morphology

\begin{tabular}{lcccc}
\hline & $\begin{array}{c}\text { Degrees of } \\
\text { Freedom }\end{array}$ & $\begin{array}{c}\text { Chi } \\
\text { Square }\end{array}$ & "Mean Square" & "F" Value \\
\hline Treatments & 6 & 720.0 & 120.0 & $12.74^{1}$ \\
$\quad$ Calcium (adj.) & $(2)$ & 411.0 & 205.5 & $21.82^{1}$ \\
$\quad$ Zinc (adj.) & $(2)$ & 252.0 & 126.0 & $13.38^{1}$ \\
$\quad$ Interaction & $(2)$ & 1.6 & 0.8 & 0.9 (115) \\
Residual & 16 & 151.0 & 9.42 & \\
\hline$\quad$ Total & 22 & 870 to 871 & & \\
\hline
\end{tabular}

$1 \mathrm{p}<.001$

Table 3. The Effect of TNC on Red Blood Cell Membrane Permeability to Zinc and Calcium

\begin{tabular}{|c|c|c|c|c|}
\hline & & $\mathrm{TNC}$ & $\begin{array}{l}\text { \% Uptake } \\
\text { of Zinc }\end{array}$ & $\begin{array}{c}\mu \text { M Uptake } \\
\text { of Zinc }\end{array}$ \\
\hline \multirow{2}{*}{\multicolumn{2}{|c|}{ (1) $0.15 \mathrm{mM}$ Zinc }} & + & 4.2 & 7.0 \\
\hline & & - & 34.8 & 58.2 \\
\hline \multirow{2}{*}{\multicolumn{2}{|c|}{ (2) $1.5 \mathrm{mM}$ Zinc }} & + & 5.4 & 82.0 \\
\hline & & - & 23.0 & 350.0 \\
\hline \multirow{3}{*}{ (3) } & $1.5 \mathrm{mM} \mathrm{Zinc} \mathrm{+}$ & + & 5.3 & 81.0 \\
\hline & $10.0 \mathrm{mM} \mathrm{Calcium}$ & - & 26.0 & 379.0 \\
\hline & & & $\begin{array}{c}\% \text { Uptake } \\
\text { of Calcium }\end{array}$ & $\begin{array}{l}\text { uM Uptake } \\
\text { of Calcium }\end{array}$ \\
\hline \multirow{2}{*}{ (4) } & $0.15 \mathrm{mM}$ Calcium & + & 0.030 & 0.045 \\
\hline & & - & 0.040 & 0.060 \\
\hline \multirow{2}{*}{ (5) } & $2.0 \mathrm{mM}$ Calcium & + & 0.050 & 1.00 \\
\hline & & - & 0.020 & 0.43 \\
\hline \multirow{2}{*}{$(6)$} & $10.0 \mathrm{mM} \mathrm{Calcium}$ & + & 0.093 & 9.32 \\
\hline & 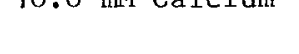 & - & 0.026 & 2.60 \\
\hline
\end{tabular}

an approxiamte F-test, also shown in Tab. 2. For the treatment responses (averaged over subjects), the simple log linear model provides an almost perfect description (see Tab. 1). 
Not only does the zinc antagonize the calcium effect but further appears to exert a morphological effect of its own (Tab. 1). This zinc effect can be seen in the increase in the percent smooth and especially the flat ghosts with the zinc-only treated cells.

We attempted to document a similar zinc-calcium antagonism with normal whole erythrocytes by treating red cells with zinc and/or calcium in the presence of TNC (see Methods). We were able to confirm the increased uptake of calcium by red cells using TNC (8) but found that zinc uptake was inhibited in the presence of TNC (Tab. 3). As shown in Tab. 3 (line 1), in the presence of $0.15 \mathrm{mM}$ zinc, the non-TNC-treated cells took up eight times more zinc than the TNC treated cells. In the presence of $1.5 \mathrm{mM}$ zinc, this difference factor is about four (Tab. 3, line 2). The addition of $10 \mathrm{mM}$ calcium to the $1.5 \mathrm{mM}$ zinc had no effect on the zinc uptake (Tab. 3, compare lines 2 and 3 ). The increase in calcium uptake in the presence of TNC can be seen by comparing lines 4-6 (Tab. 3) and is more obvious at higher calcium concentrations. At $10 \mathrm{mM}$ calcium, for example, the cells which were TNC treated took up nearly four times more calcium than the non-TNC treated control cells.

\section{DISCUSSION}

Calcium has been implicated as being an important factor in the shape change, deformability, and biochemical characteristics of the red blood cell in experimental systems employing ghosts, ATP depleted, and non ATP depleted whole cells. Exposing red cell ghosts to above-normal calcium concentrations results in a decrease in cell size (16), a change in cell shape from discocyte to echinocyte (24) and an increased membrane permeability to potassium (2). The complex relationship between calcium levels and its inhibiting-stimulating effect on $\mathrm{Na}+-\mathrm{K}+$ ATPase (20) is still under investigation. NAKAO et al. (13) were the first to point out that as the ATP concentration was decreased in incubated whole cells, the shape of these cells changed from disc to echinocyte. WEED et al. (24) subsequent1y established that calcium accumulated in these ATP depleted cells and was directly correlated with a decrease in membrane deformability. ROMERO and WHITTAM (18) found that calcium-treated ATP depleted cells show aberrant potassium and sodium fluxes as compared to noncalcium treated cells. DUNN (8) and WHITE et al. (25) were able to increase intracellular calcium in red cells not depleted of ATP and documented, again, partially reversible abnormal Na-K fluxes, decreases in cell volume and shape 
changes from discocyte to echinocyte. Calcium has been shown to be a necessary component in the drug-induced discocyte-echinocyte transformation of whole, normal red blood cells $(23)$.

The results of increasing $\mathrm{RBC}$ calcium levels are well defined and clearly deleterious to the cell. It may be significant, therefore, that zinc will antagonize the calcium and calcium-Hb interactions with ghost membranes (7) as well as improve sickle cell filterability through Nuclepore filters (4). The data presented here extends these observations. Zinc not only decreases the control level of echinocyte forms of sickle çell ghosts but effectively neutralizes the echinogenic effect of added calcium. The appearance of the flat, two-dimensional ghost membrane is correlated with the presence of zinc. This zinc effect on sickle RBC ghost morphology is probably an extension of an earlier observation with ghosts from normal RBC where it was reported that increased Hb was retained by calcium-treated ghosts as compared to ghosts made without calcium present (16). We have observed that when zinc was added together with the calcium, then much less $\mathrm{Hb}$ was retained by the ghost membranes as compared to calcium alone (7). The same results were noted in the present study with SCA RBC. The control and calcium-treated ghosts were observed to have more $\mathrm{Hb}$ color than either the zinc or zinc-calcium treated ghosts. It is not possible from the available data to specifically define the mechanism(s) of this zinc effect on ghost $\mathrm{Hb}$ retention. The zinc may compete directly with the calcium at a specific membrane site or there may be a more indirect $\mathrm{Zn}$-membrane interaction which secondarily displaces calcium and $\mathrm{Hb}$. While the mechanism of in vitro zinc action is of great interest, the major point is that the zinc-calcium antagonistic effects on ghost membrane morphology seen here further demonstrates that zinc will function as a "counter ion" to calcium.

Our experiments with TNC, which were desighed to load normal whole red cells with calcium and/or zinc, yielded varied and inconclusive results relative to the zinc-calcium antagonistic effects of cell morphology. We checked therefore whether both zinc and calcium were indeed accumulating in the TNC treated cells by adding radioactive zinc or calcium to the TNC-red cell preparation. (Tab. 3). The inhibition of red cell zinc uptake by TNC is an apparent exception to the finding that TNC inhibits anion and stimulates cation movements across red cel1 membranes as reported by GUNN and TOSTESON (11) for sheep erythrocytes. 
Little is known about the nature of zinc-RBC interaction in vivo. Having observed a reduction in irreversibly sickled cell counts (3) and a positive clinical result of oral zinc therapy with certain SCA patients during uncontrolled trials (5), we were prompted to investigate the underlying mechanism(s). At high enough concentrations, zinc will bind to intracellular $\mathrm{Hb}$ and specifically increase $\mathrm{Hb}$ oxygen affinity $(10,14,15)$; however, in vivo blood levels are not high enough to result in such an antisickling effect. Alternatively, it was found (9) that $\mathrm{RBC}^{\prime}$ s from patients with SCA contain approximately eight times more calcium than normal controls and that irreversibly sickled cells (ISC's) contain twice as much calcium as reversibly sickled cells. The implication is that the sickling and deformation so characteristic of the sickle RBC under low oxygen tensions results in an influx of calcium into the cell leading eventually to inflexibility of the cell membrane. Such a process might be involved in the red cell destruction which forms the basis for the anemia and the vascular log-jamming which produces sickle cell crisis.

The sickle red cell membrane appears therefore to be one locus of cell damage which apparently reaches its maximum in the ISC's. Despite the cellular Hb being fully oxygenated and unpolymerized, the ISC maintains its abnormal shape, consistent with these cells' containing more calcium than the reversible sickle cells. It is perhaps significant that zinc therapy with SCA patients results in an in vivo reduction in the count of irreversibly sickled cell (3) indicating, in an objective manner, the generalized effect of zinc on the sickle red cell population. Although not interpreted to constitute a final proof, we hypothesize that the in vitro zinc-calcium antagonistic relationship reported here and previously $(4,7)$ is, at least in part, the basis for the in vivo, clinical affects of zinc therapy.

This work was supported by N.I.H. Contract NO1-HB-2-2918-B, Center Grant P18 HL16008-03, and N.I.H. Training Grant 5TO1-GM-00071. We also wish to acknowledge the generous assistance of the Herrick Foundation, the Sage Foundation, Meyer Laboratories, Inc., and the Meyers Foundation.

\section{RE FERENCES}

1. BESSIS, M.: Red cell shapes. An illustrated classification and its rationale. Nouv, Rev. Fr. Hematol. 12, 721-746 (1972)

2. BLUM, R.M., HOFFMAN, J.F.: Ca-induced $\mathrm{K}$ Transport in human red cells: Localization of the Ca-sensitive site to the inside of the membrane. Biochemical and Biophysical Research Communications 46, 1146-1152 (1972) 
3. BREWER, G.J., BREWER, L.F., PRASAD, A.S.: Zinc therapy suppression of erythrocyte morphological abnormalities in sickle cell anemia (SCA). Clin. Res. 23, 522A (1975)

4. BREWER, G.J., OELSHLEGEL, F.J.: Antisickling effects of zinc. Biochemical and Biophysical Research Communications 58, 854-861 (1974)

5. BREWER, G.J., OELSHLEGEL, F.J., PRASAD, A.S.: Zinc in sickle cell anemia, In: Brewer, Erythrocythe Structure and Function, pp. 417-435, New York: Liss 1975

6. COX, D.R.: The analysis of binary data. London: Methaen 1970

7. DASH, S., BREWER, G.J., OELSHLEGEL, F.J.: Effect of zinc on haemog1obin binding by red cell membranes: Nature, Lond. 250, 251-252 (1974)

8. DUNN, M.J.: Red blood cell calcium and magnesium: Effects upon sodium and potassium transport and cellular morphology. Biochim. Biophys. Acta $352,97-116(1974)$

9. EATON, J.W., SKELTON, T.D., SWOFFORD, H.S., HOLPIN, C.E., JACOB, H.S.: Elevated erythrocyte calcium in sickle cell disease. Nature, Lond. 246, 105-106 (1973)

10. GILMAN, J.G., OELSHLEGEL, F.J., BREWER, G.J.: Hemoglobin-zinc interaction. In: Brewer, Erythrocythe Structure and Function. pp. 85-105, New York: Liss 1975

11. GUNN, R.B., TOSTESON, P.C.: The effect of 2.4,6-trinitro-m-cresol on cation and anion transport in sheep red blood cells. J. Gen. Physiol. 57, 593-609 (1971)

12. MATHESON, D.W., HOWLAND, J.L.: Erythrocyte deformation in human muscular dystrophy. Science, Wash., D.C. 184, 165-166 (1974)

13. NAKAO, M., NAKAO, T., YAMAZOE, S., YOSHIKAWA, H.: Adenosine-Triphosphate and shape of erythrocytes. J. Biochem., Tokyo 49, 487-492 (1961)

14. OELSHLEGEL, F.J., BREWER, G.J., PRASAD, A.S., KNUTSEN, C., SCHOOMAKER, E.B.: Effect of zinc on increasing oxygen affinity of sickle and normal red blood cells. Biochemical and Biophysical Research Communications. $53,560-566$ (1973)

15. OELSHLEGEL, F.J., BREWER, G.J., KNUTSEN, C., PRASAD, A.S., SCHOOMAKER, E.B.: STudies on the interaction of zinc with human hemoglobin. Arch. Biochem. Biophys. 163, 742-748 (1974)

16. PALEK, J.W., CURBY, A., LIONETTI, F.J.: Relation of Ca++-activated ATPase to Cat+-linked shrinkage of human red cell ghosts. Am. J. Physiol. $220,1028-1032(1971)$

17. PALEK, J., STEWART, G., LIONETTI, F.J.: The dependence of shape of human erythrocyte ghosts on calcium, magnesium, and adenosine triphosphate. Blood 44, 583-597 (1974)

18. ROMER0, P.J., WHITTAM, R.: The control by internal calcium on membrane permeability to sodium and potassium. J. Physiol. 214, 481-507 (1971)

19. SACHS, J.R., KNAUF, P.A., DUNHAM, P.B.: Transport through red cell membranes; in Surgenor The red blood cel1, pp. 613-695 New York: Academic Press 1975

20. SCHATZMANN, H.J., ROSSI, G.L.: $\left(\mathrm{Ca}^{2+}+\mathrm{Mg}^{2+}\right)$ - Activated membrane ATPases in human red cells and their possible relations to cation Transport. Biochim. Biophys, Acta 241, 379-392 (1971)

21. SCHOOMAKER, E.B., PRASAD, A., OELSHLEGEL, F.J., ORTEGA, J., BREWER, G.J. : Role of zinc in sickle cell disease I. Zinc deficinecy through hemolysis. C1in. Res. 21, 834 (1973)

22. SMOUSE, P.E.: Likelihood analysis of geographic variation in allelic frequencies. Theor. App. Genet. 45, 52-58 (1970) 
23. WEED, R.I., CHAILLEY, B.: The disc-echinocyte shape change of erythrocytes induced by external agents: role of calcium. In: Gerlach, Moser, Deutsch and Wilmans, Erythrocytes, Thrombocytes, Leukocytes, pp. 45-48 Stuttgart: Thieme 1973

24. WEED, R.I., LACELLE, P.L., MERRILL, E.M.: Metabolic dependence of red cel1 deformability. J. Clin. Invest. 48, 795-809 (1969)

25. WHITE, J.G., RAO, G.H.R., MUNDSCHENK, D.D.: Effects of a calcium ionophore, A23187, on the surface morphology of normal exythrocytes. p. 49. Am. Soc. Hem., 17 th Ann. Meet. 1974

Received September 20, 1976 